\title{
Stability-indicating RP-LC method for quantification of fusidic acid in cream
}

\author{
Mariane Machado Curbete*, Hérida Regina Nunes Salgado \\ Department of Pharmaceuticals, School of Pharmaceutical Sciences, UNESP - Univ Estadual Paulista, Campus de \\ Araraquara, SP, Brazil
}

\begin{abstract}
Fusidic acid is an antibiotic steroid indicated for the treatment of infections caused by the genus Staphylococcus, including methicillin resistant Staphylococcus aureus strains, and other Gram-positive bacteria. In the present study, a stability-indicating reversed-phase liquid chromatography (RP-LC) method was developed and validated for the determination of fusidic acid in dermatological cream as an alternative to existing methods. Analyses were performed using a $\mathrm{C}_{18}$ column and guard column at room temperature, eluting with an isocratic mobile phase of acetonitrile and water $(72: 28, \mathrm{v} / \mathrm{v})$, adjusted to $\mathrm{pH}$ 3.5 with acetic acid, pumped at a flow rate of $1.0 \mathrm{~mL} \mathrm{~min}^{-1}$, detection at $210 \mathrm{~nm}$ and $20 \mu \mathrm{L}$ of injection volume. The forced degradation study was conducted under acidic, alkaline, neutral, photolytic, and oxidative stress conditions. The method was validated according to ICH and FDA guidelines; it was linear, precise, accurate, selective, and robust over concentrations of 5-95 $\mu \mathrm{g} \mathrm{mL}^{-1}$, with detection and quantification limits of 0.43 and $1.31 \mu \mathrm{g} \mathrm{mL} \mathrm{m}^{-1}$, respectively. Therefore, we conclude that this method is suitable for quantifying fusidic acid in pharmaceutical dermatological creams and determining its stability, representing a more economical and practical alternative for routine analysis in quality control.
\end{abstract}

Uniterms: Fusidic acid/stability-indicating/quality control/validation. Chromatography/reversed-phase.

\section{INTRODUCTION}

Fusidic acid (FA), an antibiotic steroid (Godtfredsen, Vangedal, 1962) (Figure 1), has been used widely in the topical and systemic treatment of infections caused by Gram-positive microorganisms since 1962 (Jones et al, 2011; Spelman, 1999). These include strains resistant to penicillin and other antibiotics (França, 2010), providing an alternative for the treatment of diseases caused by methicillin resistant Staphylococcus aureus strains, abbreviated as MRSA (Anderson, 1980; Falagas, Kopterides, 2007). Topical FA is prescribed by dermatologists for the treatment of boils, carbuncles, erythema, cellulitis, folliculitis, acne, paronychia, hidradenitis, infections resulting from burns and impetigo (George, Rubin, 2003; França, 2010; Smeenk, Sebens, Houwing, 1999; Spelman, 1999; Wilkinson, 1998), atopic dermatitis, neurodermatitis, prurigo, and contact dermatitis (Long, 2008).

\footnotetext{
*Correspondence: M. M. Curbete. School of Pharmaceutical Sciences, UNESP. Universidade Estadual Paulista. Rodovia Araraquara- Jaú, km 1, 14800-901 Araraquara - São Paulo, Brazil. E-mail: mari_curbete@hotmail.com
}

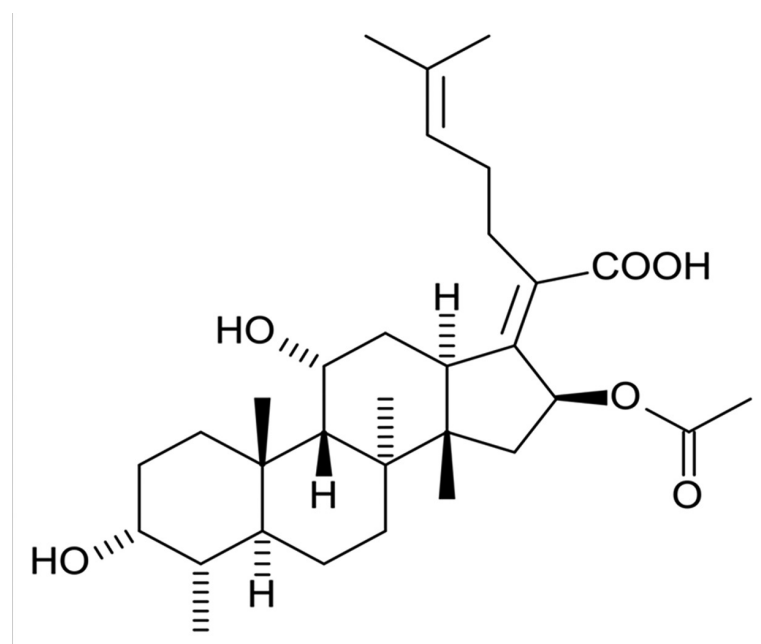

FIGURE 1 - Chemical structure of fusidic acid (CAS 6990-06-3).

Considering its importance in medical practice, the development of optimized analytical methods for the quality control of FA is essential for analyzing its quality, therapeutic efficacy, safety, and benefits for the pharmaceutical industry. Reversed phase liquid chromatography (RP-LC) is the technique of choice and 
occupies a prominent place among modern methods of analysis, due to its ease in effecting the separation, identification, and quantification of chemical substances and their degradation products (Snyder, Kirkland, Dolan, 2010).

In the literature there are some articles that describe this method for the quantification of FA in biological fluids (Hikal, 1983; Nawaz et al., 2014; Rahman, Hoffman, 1988; Sewell, Palmer, 1991; Sorense, 1988) and in pharmaceutical products (Ankam et al., 2010; British Pharmacopeia, 2010; Byrne, Velasco-Torrijos, Reinhardt, 2014, 2015; Goswami, Gupta, Jogia, 2013; Hikal, Shibl, El-Hoofy, 1982; Hong, Rong, 2012; Peh, Tan, 2000; Nawaz et al., 2014; Nianfen, Yandong, Mooling, 2009; Shaikh et al., 2009). However, some of these methods are time consuming, have complex mobile phases, or require buffer solution, while others require long running times, high injection volumes and flow rates, or high FA concentrations in the sample.

Chromatographic methods prioritizing shorter analyses that are economically viable, reduce the quantities of waste to the environment, and are safer for the analyst, are of great importance and have gained prominence (Bonfilio et al., 2009; Lopes, Salgado, 2009; Moreno, Salgado, 2008; Pedroso, Salgado, 2014; Rugani, Salgado, 2014; Silva, Salgado, 2012; Tótoli, Salgado, 2014; Vieira, Salgado, 2011).

Research improving the quality control of pharmaceutical products through analytical methods, besides benefiting the pharmaceutical industry, ensures higher product quality and increased consumer safety. In this sense, the aim of this study was to develop and validate a simple, rapid, sensitive, economic, and stability indicating method to quantify FA in pharmaceutical forms of dermatological cream, as a better alternative to existing literature methods.

\section{MATERIALS AND METHODS}

\section{Chemical and reagents}

HPLC grade acetonitrile, methanol, ethanol, and acetic acid (J. T. Baker, USA), along with deionized Milli-Q water (Millipore, Bedford, USA) were used to prepare the mobile phase. Sample Verutex ${ }^{\mathrm{TM}}$, containing $20 \mathrm{mg} \mathrm{g}^{-1}$ of the active ingredient, was supplied by LEO Pharma Laboratory (Itapevi-SP, Brazil). Fusidic acid reference standard (FA-RS), declared to be $100 \%$ pure, was purchased commercially from Sigma-Aldrich (Brazil). All adjuvants used in production of the formulation without the active ingredient (placebo) were of analytical grade: hydrochloric acid (LabSynth), cetyl alcohol (Audaz), butylated hydroxyanisole (Sigma-Aldrich, Brazil), glycerol (Ely Martins), white petrolatum (Tec-Lab), liquid petrolatum (Columbia), polysorbate 60 (LabSynth), and potassium sorbate (Rica Nata).

\section{Instrumentation and analytical conditions}

Chromatographic separations were carried out using a Waters ${ }^{\mathrm{TM}}$ HPLC system, equipped with a Waters 1525 binary gradient chromatography pump, Rheodyne Breeze 7725 i manual injector, with a $20 \mu \mathrm{L}$ loop, Waters 2487 UVVis detector, and Empower ${ }^{\mathrm{TM}}$ software. The peak purity was determined using a Shimadzu ${ }^{\mathrm{TM}}$ HPLC system equipped with two LC-10AD pumps, SIL-10AF automatic injector, DAD detector SPD-M10A-VP, communication CBM-20 module, and LC Solution software. A digital $\mathrm{pH}$ meter, model B474 (Micronal ${ }^{\mathrm{TM}}$ ), ultrasonic bath $\left(\right.$ Unique $\left.^{\mathrm{TM}}\right)$, analytical balance model DV215CD - Class I (OHAUS $\left.{ }^{\mathrm{TM}}\right)$, vacuum filtration system (Millipore ${ }^{\mathrm{TM}}$, Bedford, USA), nylon membranes $\left(0.45 \mu \mathrm{m}\right.$ pore size, Sartorius $\left.{ }^{\mathrm{TM}}\right)$, membrane filters $(0.45 \mu \mathrm{m}$ pore size and $13 \mathrm{~mm}$ diameter, Minisart $^{\mathrm{TM}}$ - RC/SRP/NY, Sartorius Stedim Biotech), and filter paper (Qualy ${ }^{\mathrm{TM}}$, J. Prolab) were also used.

Chromatographic analysis was performed using an Agilent ${ }^{\mathrm{TM}}$ Zorbax Eclipse XDB $\mathrm{C}_{18}$ column $(250 \times 4.6 \mathrm{~mm}$, $5 \mu \mathrm{m})$ combined with a pre-column HPLC Metaguard 4.6 mm Polaris $\mathrm{C}_{18}$ PTC $5 \mathrm{U}$ Agilent ${ }^{\mathrm{TM}}$ at room temperature (25 $\left.{ }^{\circ} \mathrm{C}\right)$. The mobile phase was composed of acetonitrile and water $(72: 28, \mathrm{v} / \mathrm{v})$ adjusted to $\mathrm{pH} 3.5$ with acetic acid. The flow rate was $1.0 \mathrm{~mL} \mathrm{~min}{ }^{-1}$, the detection wavelength was $210 \mathrm{~nm}$, and the injection volume was $20 \mu \mathrm{L}$.

\section{Preparation of the solutions}

\section{Preparation of standard solutions}

The stock standard solution was prepared at a concentration of $100 \mu \mathrm{g} \mathrm{mL}^{-1}$ and used to prepare working solutions by diluting to the appropriate concentration levels using the mobile phase as diluent. These solutions were filtered through $13 \mathrm{~mm}$ membranes with pore size of $0.45 \mu \mathrm{m}$ after preparation.

\section{Preparation of sample solutions}

To an amount of the cream, equivalent to a concentration of $100 \mu \mathrm{g} \mathrm{mL^{-1 }}$ weighed into a beaker, was added acetonitrile and placed into ultrasound for 10 minutes. Afterwards, the resultant solution was transferred to a volumetric flask, diluted to the necessary volume with acetonitrile, and then filtered through filter paper. Working solutions were prepared by diluting aliquots of the stock 
solution to the appropriate concentration, using the mobile phase as the diluent. These solutions were filtered through $13 \mathrm{~mm}$ membranes with pore size of $0.45 \mu \mathrm{m}$.

\section{Preparation of placebo solutions}

The stock placebo solution was prepared in the same manner as the sample, but without FA. Working solutions were prepared by diluting aliquots of the stock solution to the appropriate concentration, using the mobile phase as the diluent. These solutions were filtered through membrane filters after preparation.

\section{Development and optimization of the chromatographic method}

Various chromatographic parameters were evaluated during the development and optimization of the RP-LC method, as shown in Table I.

\section{System suitability testing}

System suitability test was performed by injecting seven replicates of the FA-RS solution at a concentration of $50 \mu \mathrm{g} \mathrm{mL}^{-1}$. The number of plates, retention factor $\left(\mathrm{k}^{\prime}\right)$, and asymmetry were evaluated according to FDA specifications (1994). In addition, the relative standard deviation (RSD) of the retention time and the chromatographic peak areas of FA were also analyzed.

\section{Method validation}

Method validation was performed following FDA (1994) and ICH (2005) specifications for linearity, precision, accuracy, selectivity, robustness, and detection and quantitation limits.
Linearity

The linearity was analyzed in triplicate, based on the results obtained from the analytical curve. The analytical curve was generated by plotting the peak area at each concentration level $(n=3)$ versus drug concentrations of 5 , $20,35,50,65,80$, and $95 \mu \mathrm{g} \mathrm{mL}^{-1}$. Statistical evaluation was performed by linear least squares regression mean (ANOVA) at a significance level of 5\%, wherein the analysis of residues was also conducted.

\section{Precision}

Precision was assessed by repeatability (intraassay) and intermediate precision (inter-assay). The precision by repeatability was verified by analysis of nine determinations covering the linear range of the method, i.e., three concentrations: low concentration $\left(5 \mu \mathrm{g} \mathrm{mL}^{-1}\right)$, medium $\left(50 \mu \mathrm{g} \mathrm{mL}^{-1}\right)$ and high $\left(95 \mu \mathrm{g} \mathrm{mL}^{-1}\right)$ obtained from the calibration curve. This procedure was performed in triplicate on the same day, under the same experimental conditions, in the same laboratory, and by the same analyst. Intermediate precision was also checked by the analysis of nine determinations covering the linear range of the method. However, this procedure was performed by different analysts on different days. In both analyses, the results were evaluated based on the RSD.

\section{Accuracy}

Accuracy was determined by recovery tests, also called recovery factors (ICH, 2005), in which known quantities of FA-RS were added to known amounts of the sample. This parameter was analyzed in triplicate at three levels of recovery from the median of the concentration curve $\left(50 \mu \mathrm{g} \mathrm{mL}^{-1}, \mathrm{R}_{2}=100 \%\right)$, wherein, $\mathrm{R}_{1}$ consisted of $80 \%\left(40 \mu \mathrm{g} \mathrm{mL}^{-1}\right)$ and $\mathrm{R}_{3}$ of $120 \%\left(60 \mu \mathrm{g} \mathrm{mL}^{-1}\right)$, as

TABLE I - Chromatographic parameters tested for development in the RP-LC method

\begin{tabular}{lc}
\hline Parameters & Description \\
\hline Mobile phase & Ethanol and water (different ratios and $\mathrm{pH})$ \\
& Methanol and water (different ratios and $\mathrm{pH})$ \\
Column & Acetonitrile and water (different ratios and $\mathrm{pH})$ \\
Guard column & Zorbax Eclipse XDB $\mathrm{C}_{18}-$ Agilent $^{\mathrm{TM}}(4.6 \times 250 \mathrm{~mm}, 5 \mu \mathrm{m})$ \\
Wavelength & Metaguard Polaris $4.6{\mathrm{~mm} 5 \mathrm{U} \mathrm{C}_{18} \mathrm{PTC}_{-} \text {- Agilent }}^{\mathrm{TM}}$ \\
Flow rate & $0.5 \mathrm{~mL} \mathrm{~min}^{-1} ; 1.0 \mathrm{~mL} \mathrm{~min}^{-1} ; 1.3 \mathrm{~mL} \mathrm{~min}^{-1}$ \\
Injection volume & $20 \mu \mathrm{L}$ \\
Elution mode & Isocratic \\
Temperature & $25 \pm{ }^{\circ} \mathrm{C}$ \\
\hline
\end{tabular}


established by the FDA (1994). The recovery percentage of the drug was calculated using Equation 1, determined by the Association of Official Analytical Chemists (2002).

$$
R(\%)=\left[\frac{C_{f}-C_{u}}{C_{a}}\right] \times 100 \quad \text { Equation } 1
$$

where $\mathrm{C}_{\mathrm{f}}$ is the total drug concentration measured after standard addition; $\mathrm{C}_{\mathrm{u}}$ is the total drug concentration in the formulation; $\mathrm{C}_{\mathrm{a}}$ is the standard concentration added to the formulation.

\section{Selectivity and studies of forced degradation}

The selectivity of the method was evaluated by observing the chromatograms of FA-RS, free analyte in the matrix (placebo), array added analyte (sample) at the working concentration of $50 \mu \mathrm{g} \mathrm{mL}^{-1}$, and the mobile phase (acetonitrile and water, 72:28, v/v, pH 3.5). The purity of the chromatographic peak of FA was analyzed using a diode array detector (DAD).

In order to assess the selectivity of the method in relation to degradation products and prove that the method was stability indicating, a forced degradation study was performed using FA solution at a concentration of $50 \mu \mathrm{g} \mathrm{mL}^{-1}$. This study was conducted under acidic $\left(0.01 \mathrm{~mol} \mathrm{~L}^{-1} \mathrm{HCl}\right.$ neutralized with $0.01 \mathrm{~mol} \mathrm{~L}^{-1}$ $\mathrm{NaOH})$, alkaline $\left(0.001 \mathrm{~mol} \mathrm{~L}^{-1} \mathrm{NaOH}\right.$ neutralized with $0.001 \mathrm{~mol} \mathrm{~L}^{-1} \mathrm{HCl}$ ), neutral (ultrapure water), oxidative $\left(3 \% \mathrm{H}_{2} \mathrm{O}_{2}\right)$, and photolytic (UV $254 \mathrm{~nm}, 20 \mathrm{~W}$ ) stress conditions. The first four reactions were carried out at $60{ }^{\circ} \mathrm{C}$, while photolytic stress, in which the solution was exposed to UV light, was conducted at room temperature. Degradation was stopped when approximately 5-20\% of the FA had degraded (Alsante et al., 2007). The degradation conditions promoted the appearance of other chromatographic peaks and their resolution was assessed.

\section{Robustness}

The robustness of the method was evaluated by Youden test through a dosage performed assay using a concentration of $50 \mu \mathrm{g} \mathrm{mL}^{-1}$. The Youden test evaluates seven variables, combined in eight experiments, in which the nominal conditions (normal) are represented by uppercase letters and the changed conditions, lower case. The variables must be consistent with practical reality and levels should reflect generally observed variation (Youden, Steiner, 1975). For this reason, changes were evaluated both with "upper" and "lower" chromatographic parameters (Table II). The results were obtained through averaging the subtraction of the values of normal conditions from the values of changed conditions. For the method to be considered robust, the differences in the values should be smaller than twice the SD of all means in the test (Youden, Steiner, 1975).

TABLE II - Chromatographic parameters and their changes "lower" and "upper" used to assess the robustness of the RPLC method

\begin{tabular}{|c|c|}
\hline Variables & $\begin{array}{l}\text { Changes "lower" } \\
\text { and "upper" }\end{array}$ \\
\hline $\begin{array}{l}\text { Lot Column Agilent } \\
(250 \times 4.6 \mathrm{~mm}, 5 \mu \mathrm{m})\end{array}$ & $\begin{array}{l}\text { A: } B 08125 \\
\text { a: } B 09180\end{array}$ \\
\hline $\mathrm{pH}$ & $\begin{array}{c}\text { B: } 3.5 \\
\text { b: } 3.4 \text { and } 3.6\end{array}$ \\
\hline Flow rate $\left(\mathrm{mL} \mathrm{min}^{-1}\right)$ & $\begin{array}{c}\text { C: } 1.0 \\
\text { c: } 0.9 \text { and } 1.1\end{array}$ \\
\hline Acetonitrile brand & $\begin{array}{l}\text { D: J. T. Baker } \\
\text { d: Tedia }\end{array}$ \\
\hline $\begin{array}{l}\text { Proportion of mobile phase } \\
\text { (acetonitrile/water) }\end{array}$ & $\begin{array}{c}\text { E: } 72: 28 \\
\text { e: } 70: 30 \text { and } 74: 26\end{array}$ \\
\hline Wavelength (nm) & $\begin{array}{c}\text { F: } 210 \\
\text { f: } 209 \text { and } 211\end{array}$ \\
\hline Temperature $\left({ }^{\circ} \mathrm{C}\right)$ & $\begin{array}{c}\text { G: } 25 \\
\text { g: } 23 \text { and } 27\end{array}$ \\
\hline
\end{tabular}

\section{Detection limit (LD) and quantitation limit (LQ)}

The LD and LQ of the method were obtained from Equations 2 and 3, respectively:

$$
\begin{array}{cc}
\mathrm{LD}=3(\mathrm{SD} / a) & \text { Equation 2 } \\
\mathrm{LQ}=10(\mathrm{SD} / a) & \text { Equation 3 }
\end{array}
$$

where SD is the standard deviation of the intersection and $a$ is the mean slope, obtained from calibration curves of the linearity study.

\section{RESULTS AND DISCUSSION}

\section{Development and optimization of the chromatographic method}

In this study we used octadecylsilane $\left(\mathrm{C}_{18}\right)$ as the stationary phase because of its easy accessibility in laboratories and ability to separate solutes of different polarities, molecular weights, and chemical features. As the sample analyzed was composed of a complex matrix, a guard column was used to remove particles that would 
have strong interactions with the stationary phase (Snyder, Kirkland, Dolan, 2010). This promoted an increased lifetime for the chromatographic column.

Regarding the analyzed mobile phases, that consisting of acetonitrile and water $(72: 28, \mathrm{v} / \mathrm{v})$ adjusted to pH 3.5 with acid acetic acid exhibited better performance, better peak definition, higher efficiency, higher sensitivity, and shorter analysis time. In addition, acetonitrile is a lower viscosity solvent than ethanol and methanol, which allows the pressure in the analysis to be very low, considerably increasing the lifetime of the column and the chromatographic system. Determination of the mobile phase $\mathrm{pH}$ was a parameter that required caution because a very acidic $\mathrm{pH}$ could compromise the integrity of the chromatographic system (Snyder, Kirkland, Dolan, 2010). Furthermore, potential ionization of the analyte should be considered when choosing $\mathrm{pH}$, so that no chromatographic peak has a low efficiency and/or peak tails. Accordingly, in mobile phases of $\mathrm{pH} \geq 4.0$, we observed a considerable decrease in chromatographic efficiency.

For the flow rate, it was observed that to obtain a satisfactory retention factor, defined by the FDA (1994) as $\geq 2$, the flow rate should be below $1.3 \mathrm{~mL} \mathrm{~min}^{-1}$. On the other hand, a flow rate of $0.5 \mathrm{~mL} \mathrm{~min}^{-1}$ promoted peak broadening, which consequently reduced chromatographic efficiency. The broadening of a chromatographic peak is a result of the processes of diffusion and mass transfer. The diffusion may either be turbulent (Eddy diffusion) or longitudinal (Snyder, Kirkland, Dolan, 2010).

Therefore, the method developed, besides being indicative of stability, had a retention time (Ankam et al., 2010; Byrne, Velasco-Torrijos, Reinhardt, 2014; Goswami, Gupta, Jogia, 2013), flow rate (Ankam et al., 2010; British Pharmacopeia, 2010; European Pharmacopeia, 2010), and injection volume (Ankam et al., 2010) lower than other methods described in the literature for the quantification of FA in dermatological cream. This results in a reduced consumption of organic solvents, thus lowering both the cost of the method and the amount of toxic waste generated to the environment.

This method also has advantages in mobile phase composition when compared with other methods (Ankam et al., 2010; Hong, Rong, 2012; Shaikh et al., 2009), because, as well as being simple, the use of buffer was avoided. Using buffer solutions is disadvantageous for the pharmaceutical industry because they are expensive, require preparation prior to analysis because storage can cause fungus growth even when refrigerated, and are generally responsible for increased pressure in the chromatographic system by causing clogging that impairs the functionality of the equipment and damages the columns, thus decreasing their useful lifetime (Snyder, Kirkland, Dolan, 2010; Watson, 2005).

\section{System suitability testing}

Tests that assess conformity of the system (system suitability) should be performed before the validation procedure or even before routine analysis. The compliance test is defined as a set of experiments designed to ensure that the equipment and the method that is being developed is able to generate results with satisfactory accuracy and precision (Paschoal et al., 2008).

According to the FDA (1994), for the system to be considered reliable and reproducible, it is necessary to perform at least two of the following tests: repeatability, resolution, asymmetry, number of plates, and retention factor. Asymmetry is a very important parameter because it prevents broadening of the chromatographic peak, which can, in turn, produce errors in measuring analytes of interest (Snyder, Kirkland, Dolan, 2010).

The number of plates can be affected by several factors, including analysis conditions, amount of sample or solute, and, in particular, column length. The retention factor is intended to ensure that the proposed method is able to produce a suitable chromatographic separation. This parameter is closely related to the retention time of the analyte. A low retention factor, provided that it is within acceptable limits, promotes lower costs, a shorter analysis, and, consequently, decreased waste production (Snyder, Kirkland, Dolan, 2010).

System suitability testing showed that the chromatographic parameters in the development of this method were able to provide accurate and reliable results, since the average value calculated for asymmetry was less than 2.0 , and the average plate number and retention factor were greater than 2000 and 2.0, respectively, as specified by the FDA (1994). Furthermore, adequate precision was observed for the values of retention time (about 8 minutes) and chromatographic peak areas of FA, which had an RSD below $2 \%$, which is recommended for conformance testing (FDA, 1994).

\section{Method validation}

\section{Linearity}

The linearity parameter was confirmed in the concentration range 5-95 $\mu \mathrm{g} \mathrm{mL}^{-1}$, wherein the calibration equation and correlation coefficient $(r)$ were $\mathrm{y}=19080 \mathrm{x}$ +7004.5 and 0.9999 , respectively. In the statistical analysis, results showed that the method had satisfactory linear regression because the $p$-value was $4.97604 \times 10^{-11}$. 
In addition, in the analysis of the waste (Figure 2), the points randomly distributed, which is also indicative of good regression.

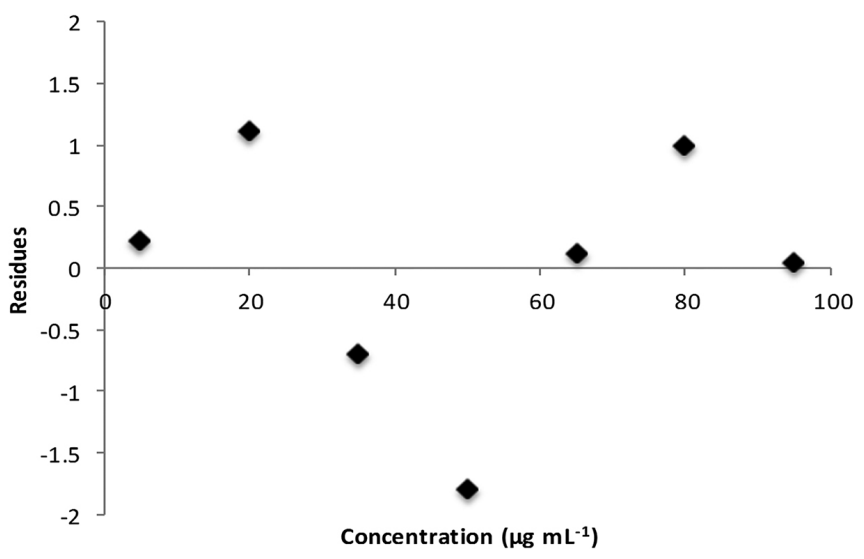

FIGURE 2 - Residue analysis for fusidic acid obtained by the RP-LC method.

\section{Precision}

In analyzing the method by repeatability and intermediate precision (Tables III and IV, respectively), the RSDs of areas obtained in all concentrations analyzed were no more than $2 \%$, indicating good precision of the chromatographic method.

Accuracy

The recovery test showed that the method had satisfactory accuracy to measure FA in dermatological cream, since the percentage value of the average recovery was close to $100 \%$, as shown in Table V.

\section{Selectivity and studies of forced degradation}

Analysis of the selectivity parameter (Figure 3) demonstrated that the adjuvants and mobile phase do not cause any interference in the peak of FA. The purity of the chromatographic peak of FA was calculated as $100 \%$ using a DAD.

TABLE III - Precision by repeatability for fusidic acid by RP-LC method

\begin{tabular}{lccc}
\hline Concentration $\left(\boldsymbol{\mu g} \mathbf{~ m L}^{-1}\right)$ & Area & Mean area $\pm \mathbf{S D}^{*}$ & RSD $^{\dagger}(\mathbf{\%})$ \\
\hline \multirow{5}{*}{5} & 108930 & $108223.67 \pm 1072.95$ & 0.99 \\
& 108752 & & \\
& 106989 & $977529.67 \pm 8086.55$ & 0.83 \\
\hline \multirow{2}{*}{95} & 977933 & & 0.89 \\
& 985407 & $1880208.33 \pm 16818.26$ & \\
\hline
\end{tabular}

${ }^{*} \mathrm{SD}=$ standard deviation; ${ }^{\dagger} \mathrm{RSD}=$ relative standard deviation.

TABLE IV - Intermediate precision for fusidic acid by RP-LC method

\begin{tabular}{|c|c|c|c|c|c|c|}
\hline \multirow{2}{*}{$\begin{array}{l}\text { Concentration } \\
\left(\mu \mathrm{g} \mathrm{mL}^{-1}\right)\end{array}$} & \multicolumn{3}{|c|}{ ANALYST $^{1}$} & \multicolumn{3}{|c|}{ ANALYST $^{2}$} \\
\hline & Area & Mean area \pm SD $^{*}$ & $\operatorname{RSD}^{\dagger}(\%)$ & Area & Mean area \pm SD $^{*}$ & $\operatorname{RSD}^{\dagger}(\%)$ \\
\hline 5 & $\begin{array}{l}108930 \\
108752 \\
106989 \\
\end{array}$ & $\begin{array}{c}108223.67 \pm \\
1072.95\end{array}$ & 0.99 & $\begin{array}{l}108812 \\
105983 \\
106281 \\
\end{array}$ & $\begin{array}{c}107025.33 \pm \\
1554.46\end{array}$ & 1.45 \\
\hline 50 & $\begin{array}{l}977933 \\
985407 \\
969249 \\
\end{array}$ & $\begin{array}{l}977529.67 \pm \\
8086.55\end{array}$ & 0.83 & $\begin{array}{l}975625 \\
990514 \\
984641 \\
\end{array}$ & $\begin{array}{c}983593.33 \pm \\
7499.59\end{array}$ & 0.76 \\
\hline 95 & $\begin{array}{l}1861386 \\
1885479 \\
1893760\end{array}$ & $\begin{array}{c}1880208.33 \pm \\
16818.26\end{array}$ & 0.89 & $\begin{array}{l}1889630 \\
1872788 \\
1854167\end{array}$ & $\begin{array}{c}1872195.00 \pm \\
17738.94\end{array}$ & 0.95 \\
\hline
\end{tabular}

${ }^{*} \mathrm{SD}=$ standard deviation; ${ }^{\circ} \mathrm{RSD}=$ relative standard deviation. 
TABLE V - Accuracy for fusidic acid by RP-LC method

\begin{tabular}{lccccc}
\hline & $\begin{array}{c}\text { FA-RS added } \\
\left(\boldsymbol{\mu g} \mathbf{~ m L}^{-1}\right)\end{array}$ & $\begin{array}{c}\text { FA-RS found } \\
\left(\boldsymbol{\mu g} \mathbf{~ m L}^{-1}\right)\end{array}$ & $\begin{array}{c}\text { Recovery } \\
(\mathbf{\%})\end{array}$ & $\begin{array}{c}\text { Mean recovery } \\
(\mathbf{\%})\end{array}$ & SD $^{\dagger}$ \\
\hline $\mathbf{R}_{\mathbf{1}}$ & 40 & 40.68 & 100.63 & 101.22 & 0.52 \\
$\mathbf{R}_{2}$ & 50 & 50.88 & 101.38 & & \\
$\mathbf{R}_{\mathbf{3}}$ & 60 & 61.16 & 101.64 & & \\
\hline
\end{tabular}

${ }^{*}$ Mean of three determinations; ${ }^{\dagger} \mathrm{SD}=$ standard deviation.

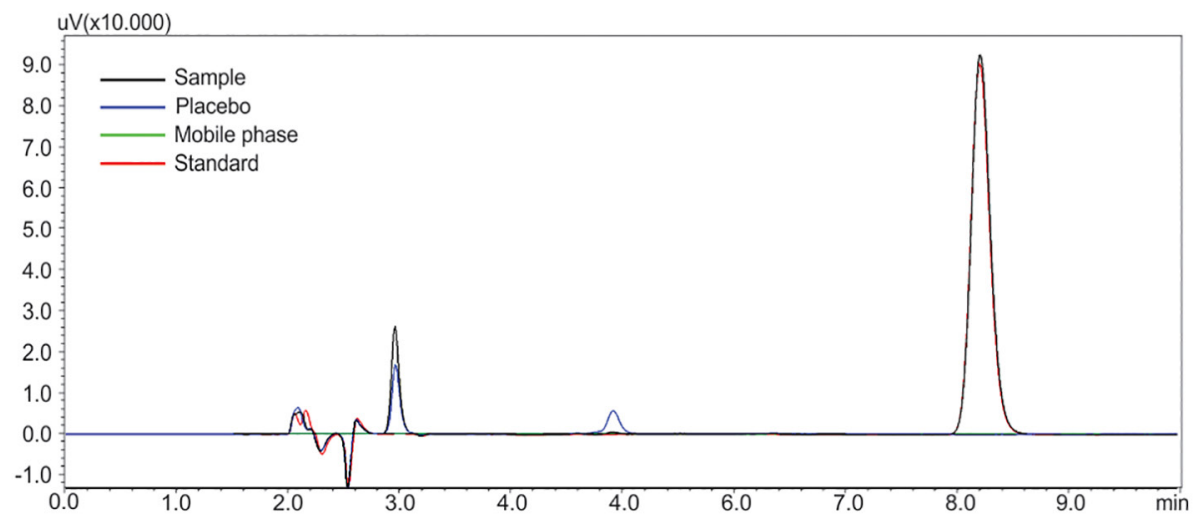

FIGURE 3 - Chromatogram showing the selectivity of the RP-LC method in the quantification of fusidic acid.

Table VI shows the results obtained under degradation conditions, namely acidic, alkaline, neutral, photolytic, and oxidative stress. Additional degradation peaks were observed under neutral, acidic, and photolytic conditions (Figure 4), in which the chromatographic resolutions were satisfactory $(2.49,11.36$, and 12.70 , respectively). Resolution is a measure of the separation between two adjacent peaks and must produce values of $\geq$ 2.0, to be judged as adequate (FDA, 1994). Under all the stress conditions there was a decrease in the peak area of FA. The drug was most stable under photolytic condition, while maximum degradation was observed under alkaline condition. All of these results combined to demonstrate that the method, as well as being selective, is indicative of stability, because it was able to differentiate FA from the other degradation products observed.

\section{Robustness}

In the analysis of robustness using the Youden Test, no significant effect was observed in the method when subjected to the proposed changes, because all "lower" changes had effects lower than 1.94 and all "upper" changes had effects lower than 1.10 (Table VII). These values corresponded with the values of twice the SD of all the means of the respective assays $(0.97$ and 0.55 , respectively).

This test not only assessed whether the method is
TABLE VI - Forced degradation study of fusidic acid

\begin{tabular}{|c|c|c|}
\hline Stress condition & Time & Degradation (\%) \\
\hline $\begin{array}{l}\text { Acid hydrolysis } \\
\left(0.01 \mathrm{~mol} \mathrm{~L}^{-1} \mathrm{HCl}\right)\end{array}$ & $\begin{array}{c}0 \mathrm{~h} \\
1 \mathrm{~h} \\
5 \mathrm{~h} \\
9 \mathrm{~h} \\
24 \mathrm{~h}\end{array}$ & $\begin{array}{c}3.23 \\
4.32 \\
7.78 \\
14.48 \\
30.10\end{array}$ \\
\hline $\begin{array}{l}\text { Alkaline hydrolysis } \\
\left(0.001 \mathrm{~mol} \mathrm{~L}^{-1} \mathrm{NaOH}\right)\end{array}$ & $\begin{array}{l}0 \mathrm{~h} \\
1 \mathrm{~h}\end{array}$ & $\begin{array}{l}17.97 \\
35.20\end{array}$ \\
\hline Neutral (ultrapure water) & $\begin{array}{c}0 \mathrm{~h} \\
1 \mathrm{~h} \\
5 \mathrm{~h} \\
9 \mathrm{~h} \\
24 \mathrm{~h} \\
48 \mathrm{~h} \\
72 \mathrm{~h}\end{array}$ & $\begin{array}{c}0.50 \\
0.75 \\
1.00 \\
3.78 \\
7.38 \\
14.26 \\
27.70\end{array}$ \\
\hline Photolytic (UV 254 nm) & $\begin{array}{c}0 \mathrm{~h} \\
1 \mathrm{~h} \\
5 \mathrm{~h} \\
9 \mathrm{~h} \\
24 \mathrm{~h} \\
48 \mathrm{~h} \\
6 \text { days } \\
10 \text { days }\end{array}$ & $\begin{array}{c}0.35 \\
0.63 \\
1.08 \\
4.36 \\
3.92 \\
6.25 \\
6.33 \\
13.93\end{array}$ \\
\hline Oxidation $\left(3 \% \mathrm{H}_{2} \mathrm{O}_{2}\right)$ & $\begin{array}{l}0 \mathrm{~h} \\
1 \mathrm{~h} \\
5 \mathrm{~h}\end{array}$ & $\begin{array}{c}5.01 \\
14.33 \\
95.84\end{array}$ \\
\hline
\end{tabular}



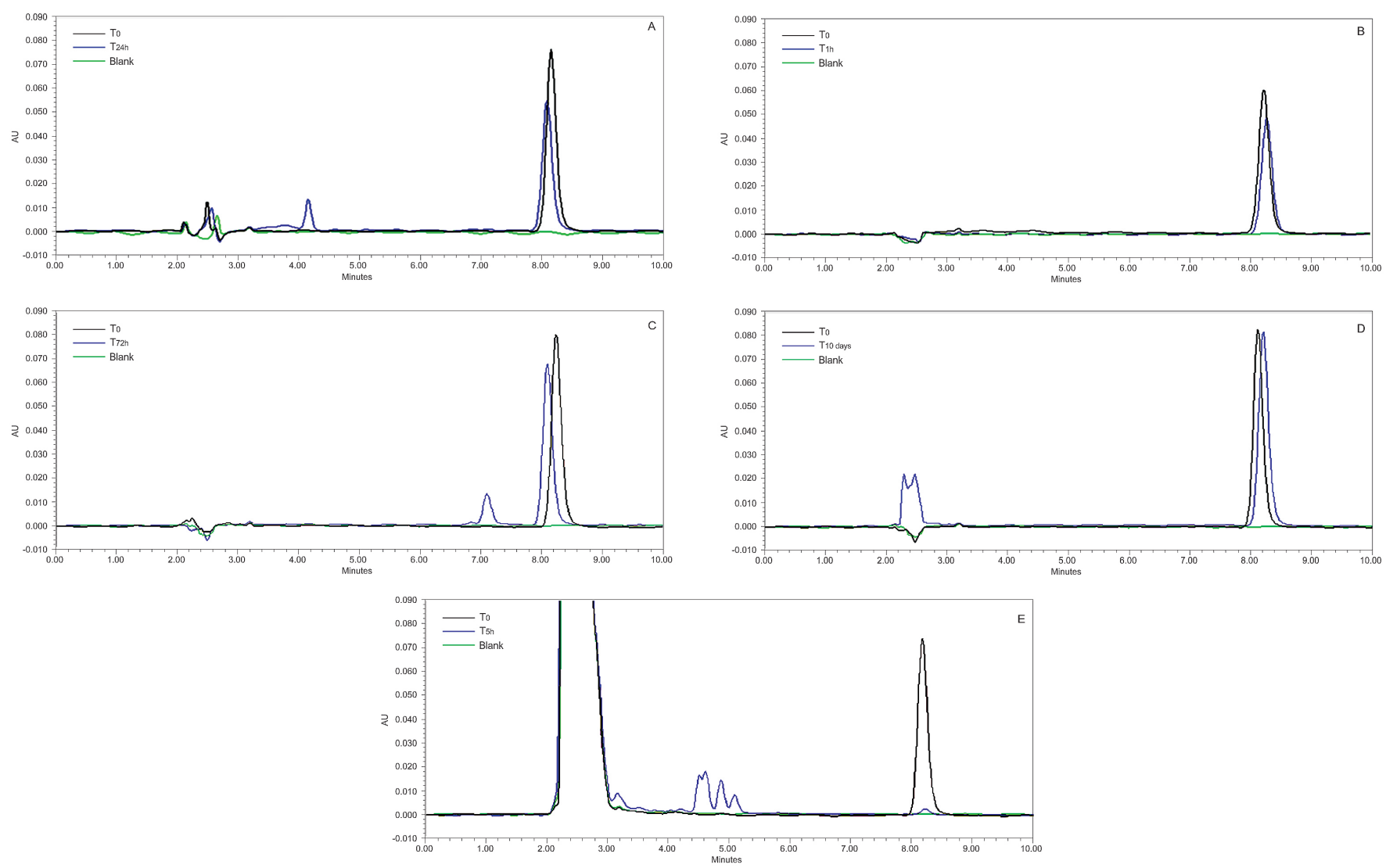

FIGURE 4 - Chromatograms obtained in the forced degradation study of fusidic acid. Degradation conditions: A: Acid hydrolysis $\left(0.01 \mathrm{~mol} \mathrm{~L}^{-1} \mathrm{HCl}\right)$, B: Alkaline hydrolysis $\left(0.001 \mathrm{~mol} \mathrm{~L}^{-1} \mathrm{NaOH}\right), \mathbf{C}$ : Neutral (ultrapure water), D: Photolytic (UV $\left.254 \mathrm{~nm}\right)$, and E: Oxidative stress $\left(3 \% \mathrm{H}_{2} \mathrm{O}_{2}\right)$.

TABLE VII - Effects observed in the robustness evaluation of the RP-LC method

\begin{tabular}{lcc}
\hline \multirow{2}{*}{ Variable } & \multicolumn{2}{c}{$\mid$ Effects $\mid$} \\
\cline { 2 - 3 } & $\begin{array}{l}\text { Changes } \\
\text { "lower" }\end{array}$ & $\begin{array}{c}\text { Changes } \\
\text { "upper" }\end{array}$ \\
\hline Lot Column Agilent ${ }^{\mathrm{TM}}$ & 0.37 & -0.20 \\
$(250 \times 4.6 \mathrm{~mm}, 5 \mu \mathrm{m})$ & & \\
$\mathrm{pH}$ & -0.51 & 0.68 \\
Flow rate $\left(\mathrm{mL} \mathrm{min}^{-1}\right)$ & 0.32 & 0.29 \\
Acetonitrile brand & 0.58 & 0.33 \\
Proportion of mobile phase & -1.35 & -0.45 \\
(acetonitrile and water) & & \\
Wavelength $(\mathrm{nm})$ & 0.22 & -0.39 \\
Temperature $\left({ }^{\circ} \mathrm{C}\right)$ & -0.77 & -0.05 \\
\hline
\end{tabular}

robust, but also indicates the influence of each parameter on the analytical results. The premise of the test is to introduce many changes at once in order to determine the effect of individual changes (Youden, Steiner, 1975). In this instance, the effects obtained from variation of the different parameters were not significant and therefore the method was considered robust.

\section{Detection limit (LD) and quantitation limit (LQ)}

The values calculated for the LD and LQ were 0.43 $\mu \mathrm{g} \mathrm{mL} \mathrm{m}^{-1}$ and $1.31 \mu \mathrm{g} \mathrm{mL}^{-1}$, respectively. These values indicated the ability of the method to reliably detect and quantify FA dermatological cream formulations established in the linear range.

\section{CONCLUSION}

The proposed RP-LC method for the quantification of FA in the form of pharmaceutical dermatological cream is fast, simple, efficient, economical, and sensitive compared to other methods described in the literature, and is stability indicating. All parameters were in accordance with the acceptance criteria for the validation of methods established by the ICH and FDA. Therefore, the validated method could easily be applied to the routine analysis of FA in the pharmaceutical industry. 


\section{ACKNOWLEDGEMENTS}

We are very grateful to the FAPESP (Project 2013/02861-3) for financial support, LEO Pharma (Itapevi-SP, Brazil) for donating the medicine, Agilent Technologies for donating analytical columns, and PADC/ FCF/UNESP (Araraquara, Brazil) for their support.

\section{REFERENCES}

ALSANTE, K. M.; ANDO, A.; BROWN, L.; ENSING, J.; HATAJIK, T. D.; KONG, W.; TSUDA, Y. The role of degradant profiling in active pharmaceutical ingredients and drug products. Adv. Drug Deliv. Rev., v. 59, n. 1, p. 29-37, 2007.

ANDERSON, J. D. Fusidic acid: new opportunities with an old antibiotic. Can. Med. Assoc. J., v. 122, n. 7, p. 765-769, 1980.

ANKAM, R.; MUKKANTI, K.; DURGAPRASAD, S.; NAIDU, P.V.L. Simultaneous determination of halobetasol propionate and fusidic acid related substances by reversed phase high performance liquid chromatographic method. Asian J. Chem., v.22, n.5, p.3369-3375, 2010.

ASSOCIATION OF OFFICIAL ANALYTICAL CHEMISTS. AOAC. Official methods of analysis: appendix D: guidelines for collaborative study procedures to validate characteristics of a method of analysis. 18. ed. Gaithesburg: AOAC, Gaithersburg, MD, 2002.

BONFILIO, R.; TARLEY, C.R.T.; PEREIRA, G.R.; SALGADO, H.R.N.; ARAÚJO, M.B. Multivariate optimization and validation of an analytical methodology by RP-HPLC for the determination of losartan potassium in capsules. Talanta, v.80, n.1, p.236-241, 2009.

BRITISH PHARMACOPEIA. London: The Stationary Office, 2010. v.3, p.2724-2727

BYRNE, J.; VELASCO-TORRIJOS, T.; REINHARDT, R. An RP-HPLC method for the stability-indicating analysis of impurities of both fusidic acid and betamethasone-17valerate in a semi-solid pharmaceutical dosage form. $J$. Chromatogr. Sci., v.53, n.9, p.1498-1503, 2015.
BYRNE, J.; VELASCO-TORRIJOS, T.; REINHARDT, R. Development and validation of a novel stability-indicating HPLC method for the simultaneous assay of betamethasone17-valerate, fusidic acid, potassium sorbate, methylparaben and propylparaben in a topical cream preparation. J. Pharm. Biomed. Anal., v.96, p.111-117, 2014.

EUROPEAN PHARMACOPEIA. 7. ed. Strasbourg: Council of Europe, 2010. v.2, p.2079-2080.

FALAGAS, M.E.; KOPTERIDES, P. Old antibiotics for infections in critically ill patients. Curr. Opin. Crit. Care, v.13, n.5, p.592-597, 2007.

FOOD AND DRUG ADMINISTRATION. FDA. Validation of chromatographic methods. Washington: Center for Drug Evaluation and Research, 1994.

FRANÇA, F.F.A.C. Andrejus Korolkovas Dicionário terapêutico Guanabara. Edição 2009/2010, Rio de Janeiro: Guanabara Koogan, 2010.

GEORGE, A.; RUBIN, G. A systematic review and metaanalysis of treatments for impetigo. Br. J. Gen. Prac., v.53, n.491, p.480-487, 2003.

GODTFREDSEN, W.O.; VANGEDAL, S. The structure of fusidic acid. Tetrahedron, v.18, n.9, p.1029-1048, 1962.

GOSWAMI, N.; GUPTA, V.R.M.; JOGIA, A.H. Development and validation of a novel stability-indicating RP-HPLC method for the simultaneous determination of halometasone, fusidic acid, methylparaben, and propylparaben in topical pharmaceutical formulation. Sci. Pharm., v.81, n.2, p.505$518,2013$.

HIKAL, A.H. Assay of fusidic acid in plasma by highperformance liquid chromatography. Int. J. Pharm., v.13, n.3, p. 297-301, 1983.

HIKAL, A.H.; SHIBL, A.; EL-HOOFY, S. Determinations of sodium fusidate and fusidic acid in dosage forms by highperformance liquid chromatography and a microbiological method. J. Pharm. Sci., v.71, n.11, p.1297-1298, 1982.

HONG, C.; RONG, Z. Determination of dexamethasone acetate and fusidic acid in compound dexamethasone and fusidic acid cream. Chin. J. Antibiotics, v.12, p.924-926, 2012. 
INTERNATIONAL CONFERENCE ON HARMONIZATION OF TECHNICAL REQUIREMENTS FOR REGISTRATION OF PHARMACEUTICALS FOR HUMAN USE. ICH. Validation of analytical procedure: Text and methodology Q2(R1). Switzerland: ICH Steering Committee, 2005. Available at: $<$ http://www.ich.org/ fileadmin/Public Web Site/ICH Products/Guidelines/ Quality/Q2_R1/Step4/Q2_R1_Guideline.pdf $>$. Accessed on: 09 November 2015.

JONES, R.N.; MENDES, R.E.; SADER, H.S.; CASTANHEIRA, M. In vitro antimicrobial findings for fusidic acid tested against contemporary (2008-2009) Gram-positive organisms collected in the United States. Clin. Infect. Dis., v.52, supl.7, p.S477-S486, 2011.

LONG, B.H. Fusidic acid in skin and soft-tissue infections. Acta Derm. Venereol., supl.216, p.14-20, 2008.

LOPES, C.C.G.O.; SALGADO, H.R.N. Development of a validated stability-indicating LC assay and stress degradation studies of linezolid in tablets. Chromatogr., v.69, supl., p.S129-S135, 2009.

MORENO, A.H.; SALGADO, H.R.N. Microbiological assay for ceftazidime injection. J. AOAC Int., v.90, n.5, p.13791382, 2007.

NAWAZ, M.; ARAYNE, M.S.; SULTANA, N.; HAIDER, A.; HISAINDEE, S. Simultaneous determination of fusidic acid and steroids from bulk drugs and human plasma by reversed phase HPLC. Acta Chromatogr., v.26, n.1, p.57-66, 2014.

NIANFEN, C.; YANDONG, W.; MOOLING, C. Determination of fusidic acid ophthalmic emulsion by HPLC. China Med. Herald, v. 22, p. 72-73, 2009.

PASCHOAL, J.A.R.; RATH, S.; AIROLDI, F.P.S.A.; REYES, F.G.R. Validação de métodos cromatográficos para a determinação de resíduos de medicamentos veterinários em alimentos. Química Nova, v.31, n.5, p.1190-1198, 2008.

PEDROSO, T.M.; SALGADO, H.R.N. Validation of analytical methodology for quantification of cefazolin sodium pharmaceutical dosage form by high performance liquid chromatography to be applied for quality control in pharmaceutical industry. Braz. J. Pharm. Sci., v.50, n.1, p.213-223, 2014.
PEH, K.-K.; TAN, Y.T. Simple high-performance liquid chromatographic method for simultaneous determination of fusidic acid and betamethasone dipropionate in a cream formulation. Int. J. Pharm. Compd., v.4, n.3, p.229-231, 2000.

RAHMAN, A.; HOFFMAN, N.E. High-performance liquid chromatographic determination of fusidic acid in plasma. J. Chromatogr., v.433, p.159-166, 1988.

RUGANI, K.S.; SALGADO, H.R.N. Stability-indicating LC method for the determination of cephalothin in lyophilized powder for injection. Anal. Meth., v.6, p.4437-4445, 2014.

SEWELL, G.J.; PALMER, A.J. The chemical and physical stability of three intravenous infusions subjected to frozen storage and microwave thawing. Int. J. Pharm., v. 2, n.1, p.57-63, 1991

SHAIKH, S.; MUNEERA, M.S.; THUSLEEM, O.A.; TAHIR, M.; KONDAGULI, A.V. A simple RP-HPLC method for the simultaneous quantitation of chlorocresol, mometasonefuroate, and fusidic acid in creams. $J$. Chromatogr. Sci., v.47, n.2, p.178-183, 2009.

SILVA, L.M.; SALGADO, H.R.N. Validation of a stabilityindicating RP-LC method for the determination of tigecycline in lyophilized powder. J. Chromatogr. Sci., v.51, n.2, p.192-199, 2012.

SMEENK, G.; SEBENS, F.W.; HOUWING, R.H. Use and adverse reactions of local antibiotics and disinfectants on the skin. Ned. Tijdschr. Geneeskd., v.143, n.22, p.1140$1143,1999$.

SNYDER, L.R.; KIRKLAND, J.J.; DOLAN, J.W. Introduction to modern liquid chromatography. 3. ed. New York: John Wiley \& Sons, 2010.no. de páginas ??

SORENSE, N.H. Liquid chromatographic determination of fusidic acid in serum. J. Chromatograph., v.430, n.2, p.400405, 1988.

SPELMAN, D. Fusidic acid in skin and soft tissue infections. Int. J. Antimicrob. Agents, v.12, supl., p.S59-S66, 1999.

TÓTOLI, E.G.; SALGADO, H.R.N. Development and validation of an economic, environmental friendly and stability-indicating analytical method for determination of ampicillin sodium for injection by RP-HPLC. World $J$. Pharm. Sci., v.3, n.6, p.1928-1943, 2014. 
VIEIRA, D.C.M.; SALGADO, H.R.N. Comparison of HPLC and UV spectrophotometric methods for the determination of cefuroxime sodium in pharmaceutical products. $J$. Chromatogr. Sci., v.49, n.7, p.508-511, 2011.

WATSON, D.G. Pharmaceutical analysis: a textbook for pharmacy students and pharmaceutical chemists. London: Elsevier, 2005. No. de páginas
WILKINSON, J.D. Fusidic acid in dermatology. Br. J. Dermatol., v.139, supl.53, p.37-40, 1998.

YOUDEN, W.J.; STEINER, E.H. Statistical Manual of AOAC: Association of Official Analytical Chemistry. Washington: AOAC, 1975. 88p.

Received for publication on $11^{\text {st }}$ August 2015 Accepted for publication on $15^{\text {th }}$ August 2016 
